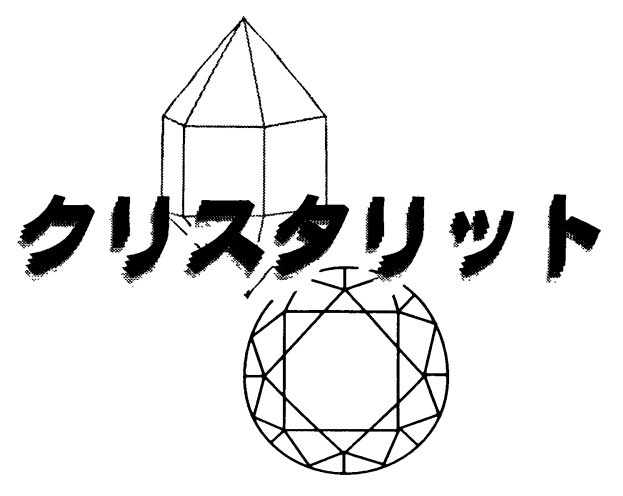

ドフィーネ双晶

\section{Dauphiné Twinning}

天然に成長した水晶では, 方位的に, 三方晶系の $\mathrm{c}$ 軸 (双 晶軸)の周りの $180^{\circ}$ の回転によって関係付けられる右水 晶 $\left(P 3_{2} 21\right)$ 同士あるいは左水晶 $\left(P 3_{1} 21\right)$ 同士が, 慣入して 双晶を形成していることがある.ドフィーネ双晶はこのよ うな双晶であり, $\mathrm{a}$ 軸 (2 回対称軸, $\mathrm{X}$ 軸) が逆平行になる ため, 2 個体で圧電気の極性が逆転する. 光学的手段によ っては区別できないと言われるが, エッチングによって2 個体を識別できることが知られている．原子のわずかの变 位 (室温で酸素約 $0.8 \AA$ ) で双晶方位が交換できるため, 温 度上昇, ずれ応力等によっても容易に単結晶内に 2 つの双 晶方位を取る構造が形成される. 特に転移点以上の温度か ら冷却された結晶は, いわゆる転移双晶として,この形式 の双晶となることがある.これらの場合, 回折強度は影響 を受け，極端な場合には，見かけの対称上昇 $\left[6^{\prime} 22^{\prime}=\left(3.2^{\prime}\right)\right.$ 22']に対応して, 六方回折対称を与えることがある.

（金沢大学理学部 木原國昭）

\section{密度汎関数理論 DFT Theory}

原子・分子の電子状態は波動関数で表現されるが, こ れは多变数関数であるため正確に求めるのは困難である. 密度汎関数理論では多体系の基底状態を構成粒子の電子 密度分布だけから計算できることを示した理論で, 金属 や半導体の性質の理解に有用である. 分子軌道法が主に 非周期境界条件で核の周辺に局在した電子の問題を解く ことに利用されることが一般的であるのに対し, 金属な どのように自由電子からの摂動で近似する時は密度沉関 数理論やバンド計算法が使われてきた。また, 時間依存 の運動方程式を解こうとする方法は分子動力学法と呼ば れ,これは構造精密化のプログラム・X-PLOR／CNSに も応用されている. 近年, 密度沉関数理論による計算結 果がいろいろな化学物質の電子状態の計算にも有効であ ることが示され利用されつつある。

(京都大学大学院理学研究科 书口芳樹)

\section{顕微分光法 \\ Microscope-Spectroscopy}

顕微分光法とは顕微鏡の光学系を使った分光法のことで, 色々な波長領域での透過, 反射ならびに蛍光スペクトルの 解析を行う. 紫外. 可視領域ではレンズ系, また赤外線領 域 (顕微FT-IR) ではカセグレン系 (鏡面光学系) が用いられ る.顕微ラマン装置でもレンズ系が使用されている、いず れの顕微装置でも微少面積のスペクトル解析を目的として いる. 測定試料が薄膜の場合には透過スペクトル, また単 結晶の場合には反射スペクトルを測定することが多い. 特 に, 色々な結晶面における偏光反射スペクトルは電子構造 に関する多くの知見を与え, 結晶構造解析から得られた分 子配列の情報を基に電子構造を詳細に解析することができ る。例えば，分子面や分子の積層方向に沿った偏光反射ス ペクトルでは分子の遷移モーメントの方向や分子間電荷移 動スペクトルの検討も可能である.また, 遷移モーメント 間の相互作用 (“励起子結合効果”) に関する情報も得られる。

(横浜国立大学工学研究院 水口 仁)

\section{フォノン状態密度 \\ Phonon Density of States}

一般に固体中の原子の運動は, その振幅が小さいとき には規準振動に解析することができ, 量子論の立場で運 動量 (波長) とエネルギー(振動数) で区別される準粒子 すなわちフォノンとして扱うことができる. 各振動数の フォノンの数を運動量空間の第一ブリュアン・ゾーンに ついて積分して得られるのが(調和近似での) 格子振動の 状態密度である．実験的には運動量による分解をせずに 積算した中性子の非弾性散乱スペクトルとして観測する ことができる.熱容量 (比熱)は運動量に対し選択則を持 たないので, フォノン状態密度を反映する.デバイモデル では, 状態密度はある有限の振動数までを連続弾性体近 似により振動数の 2 次関数, それ以上では 0 と仮定する。 現実には結晶のフォノン分散関係は複雑であるために, デ バイの熱容量式では熱容量の実験值の定量的な再現は十 分でない. また格子構造 (周期性) を持たない非晶質でも 状態密度を考えることができ，実験的にも観測できる，結 晶, 非晶質いずれの場合も, 元来, 振幅の小さな調和振 動（すなわち低温での格子振動）を対象としていたが, 高 温では非調和性の影響も含んだ上での状態密度が観測さ れるから,議論の際には注意を要する.

(東京工業大学応用セラミックス研究所 東條壮男) 


\section{覀粒界 \\ Sub-grain Boundary}

結晶粒子内に発達した転位が, 転位の歪エネルギーを 下げるため粒内で再配列をおこす。その際，ある特定の 面内に再配列し，その面を隔て結晶方位がわずかに異な る亜粒子 (sub-grain) を形成する．その亜粒子を境する面 を亜粒界と呼ぶ。下図は, 粒子内の刃状転位が再配列を 行い, 亜粒界が形成されるのを模式化したものである.転 位が，面内に集積するにつれ，境された粒子のミスオリ エンテーションは増加する。この増加が続くと, やがて, 覀粒界は，通常の粒界とみなされるようになる．刃状転 位が，そのすべり面に垂直な面内に並んだものが，代表 的な亜粒界の構造である。
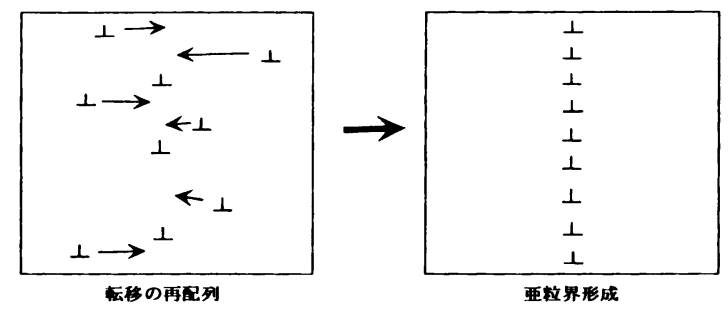

(Dept. of Geology and Geophysics, Univ. of Minnesota 平賀岳彦)

\section{軸発散効果}

\section{Axial Divergence Effect}

角度分散型の粉末回折測定において，入射ビームまた は回折ビームがゴニオメータの軸方向, つまりゴニオメ 一夕の回転面と垂直な方向に発散を持つことによる光学 的な収差の影響を軸発散効果または垂直発散効果 vertical divergence effect と呼ぶ.この効果によって回折角が約 $90^{\circ}$ よりも低い回折ピークは低角側にシフトするととも にピークの低角側に裾を引く非対称な形状を示し, 約 $90^{\circ}$ より高い角度の回折ピークではこれとは逆の挙動が あらわれる. 通常の回折計では, 軸発散効果の影響を軽 減するために光路中に金属箔を等間隔に配置したソーラ ースリットSoller slits が挿入されているが, それでも普 通の測定条件では実測の回折ピークが示す非対称性の最 も大きな要因となる．この効果の定性的な説明について は古くから知られていたが, 実験室型の粉末 X 線回折計 の軸発散効果を定量的に取り扱うための数学的な形式は, 筆者が1998年に初めて見出したものである.

(名古屋工業大学セラミックス基盤工学研究センター 井田 隆)

\section{たたみこみの計算 Calculation of Convolution}

たたみこみ convolution は合成積または重畳, folding と 呼ばれることもあり, 関数 $f(x)$ と $g(x)$ のたたみこみの定 義は次の式であらわされる。

$$
f(x) \otimes g(x) \equiv \int_{-\infty}^{\infty} f(x-y) g(y) d y
$$

一般的に, 実測の回折ピーク形状は, 試料固有の回折 ピーク形状に装置の影響を表す関数 (装置関数) がたたみ こまれたものであると解釈される．ピーク形状に対する フィッティングによるデータ解析において, 装置の影響 を正しく考慮するためには, 装置関数がたたみこまれた 形式のモデル関数を用いるか, あるいはFourier 変換を用 いた「逆たたみこみ」deconvolutionを施して元のデータか ら装置関数の影響を取り除けば良い。ただし, 逆たたみ こみによるデータ処理では測定誤差の影響を正しく考慮 することがやや困難になる傾向がある．実際にたたみこ みを計算するためには, 解析的な解あるいはその近似形 式を用いる方法と, 数值積分を用いる方法, また Fourier 変換を用いる方法とがある。

(名古屋工業大学セラミックス基盤工学研究センター 井田 隆)

\section{吸収係数と試料の透過性の効果 Absorption Coefficient and Effect of Sample Transparency}

$\mathrm{X}$ 線に対する試料の線吸収係数は, 試料の密度と組成, 構成元素の質量吸収係数から見積もられる. 線吸収係数 の逆数は侵入深さ penetration depth と呼ばれ, 典型的な有 機物の粉末では $\mathrm{CuK} \alpha$ 特性 X 線に対して $1 \mathrm{~mm}$ 程度の值 を示し，重元素を含む物質ではこれよりも小さい値にな る. 粉末回折測定では, 反射法の場合には侵入深さが試 料の厚さと同程度かそれ以上の場合に, また透過法の場 合には侵入深さが試料の厚さと同程度かそれ以下の場合 に, 単結晶法と同じように回折強度の補正が必要になる。 また, 最も一般的な通常線源, 平板状の試料を用いた集 中法一反射型 (Bragg-Brentano 型) の粉末回折測定では, 試料の透過性によって回折ピーク位置がシフトするとと もに, 線幅が広がり, 形状が非対称化される効果があら われる.この効果の大きさは概ね侵入深さとゴニオメー 夕半径の比の逆正接であらわされ，外部標準試料を用い た格子定数の評価などの目的ではこのことを考慮する必 要がある.

(名古屋工業大学セラミックス基盤工学研究センター 井田 隆) 